\title{
Some English Names of Clothing Ending in -wear
}

\author{
David L. Gold
}

Webster's Third New International Dictionary of the English Language: Unabridged (1961) notes objectively that the word wear is "often used in combination". Not everyone, however, has been satisfied with all the combinations.

In A History of Modern Colloquial English (Oxford, Basil Blackwell, 1936), Henry Cecil Wyld wrote: “[...] we may begin our brief catalogue of curiosities, and we thus designate them not because of any inherent strangeness or eccentricity in the words themselves, but on account of the curious fact that what are normal and natural elements of speech in some circles, are regarded in others as 'vulgar' and laughable. We may begin with what have been called 'shopwalker words', such as vest for waistcoat, singlet for vest, neckwear for ties, footwear for boots and shoes. It is possible that some regard all these terms as graceful and elegant modes of expression, far superior to the homelier words which they displace. On the other hand, there are many speakers who would as soon think of uttering horrible oaths before ladies, as of using such words seriously" (p. 17).

Almost fifty years later, -wear was condemned again. In I Stand Corrected: More on Language (New York, Times Books, 1984), William Safire first quoted Marilyn Plummer ("a new 'retailese' I've been seeing and hearing in the media: the new fascination with -wear") and then went on to say that "She instances eyewear, footwear, neckwear, swimwear. 'I realize that they're probably catchall words to cover, in the case of eyewear, glasses and contact lenses. But I have just become aware of a preponderance of these -wear words in the past year or so.' She is right on both counts: sometimes a vogue word and sometimes a useful generic" (p. 82). ${ }^{1}$

Wyld and Plummer might have been surprized to learn that the Oxford English Dictionary has a quotation for neckwear dated 1879 and that because the source quoted is a dictionary we may take the word to have been at least fairly widespread by that year. Eyewear, as Plummer realized, is indeed useful as a collective noun referring to all kinds of eyeglasses (including goggles) and contact lenses:

1. "[...] 65 percent of the population uses corrective eyewear [...]" (John Tagliabue, “An Eyewear King's U.S. Push," The New York Times, 1 April 1995, pp. 35 and 38; the 
quotation is from page 38).

2. "For Williams and roughly 1 million of the world's other dysfunctional spectators, laser vision correction has been a windfall: quick, safe and the end of cumbersome eyewear" ("Focus on Your Health: Zapping the Eye," Newsweek, 2 June 1997, pp. 80-81; the quotation is from page 80).

3. "An exhibition chronicling the history of eyewear in New York, from eighteenthcentury spectacles to twentieth-century driving goggles" (The New Yorker, 17 November 1997, p. 122).

The word eyewear enjoys some popularity for two more reasons:

1. Since many people, at least initially, feel uncomfortable about wearing prosthetic devices, likening eyeglasses to clothing may ease their discomfort. Eyewear can thus serve as a euphemism.

2. Turning eyeglasses from a prosthetic device into a article of clothing allows manufacturers and sellers to exploit its commercial value (a range of frames can be marketed; frames can change as fashions change; and people might be encouraged to buy several pair of eyeglasses, with frames to match various other articles of clothing or suit various occasions). ${ }^{2}$

Neckwear too is useful, for the reason Marilyn Plummer gave -- the word covers bolo ties, bow ties, neckties, collars, necklaces, and anything else that can go around the neck or on it:

1. "But despite the obvious drawbacks, Mr. Carlson couldn't bring himself to change his choice of neckwear" (Warren St. John, "A Red Flag That Comes in Many Colors," The New York Times, 26 June 2005, Styles Section, p. 2), which refers to Tucker Carlson's preference for bow ties and where a generic term is needed.

2. Arizona has an official piece of neckwear, the bolo tie. Calling the bolo tie *"the official tie of Arizona" would be misleading because that wording would imply, wrongly, that any number of kinds of neckwear that are not ties may be official.

3. At least since 2002 the United States has had a National Neckwear Association (at 51 Chambers Street, New York, New York), the members of which manufacture not just ties but other kinds of neckwear too. Here too, then, a broader term is needed.

Among the sixty lexemes which a scoffing John Leo gave as examples of how "English is a living language, ever on the move to more euphemisms and more useful and evasive terms" were eight ending in -wear (the definitions, which are his, are also the substitutes he would like to see used): eyewear 'glasses', footwear 'shoes and boots', innerwear 'underwear', outerwear 'coats', shapewear 'girdles', sleepwear 'pajamas', slimwear 'girdles', and swimwear 'bathing suits' (John Leo, "And this means... A guide to deciphering PC lingo," Daily News, New York, 28 August 1999, p. 27). Most of the eight are in fact not euphemistic or evasive, but, rather, more comprehensive than his definitions.

With words ending in -wear we find the full range of currency: widespread, established words; words used only in the clothing industry; words used only in advertizing; infrequent words; vogue words; words used only in the names of businesses; serious nonce words; 
jocular nonce words; and possibly other categories too. ${ }^{3}$

Many of the words are semantically interrelated in one of several ways:

1. Synonyms, like bedwear, nightwear, sleepwear, and slumberwear.

2. Antonyms, like daywear and eveningwear; daywear and nightwear.

3. Hyponyms and hyperonyms. For example, actionwear and activewear subsume cyclewear, gymwear, skiwear, and so on. Racewear is a kind of athleticwear. In one sense of sportswear, the word subsumes dancewear, golfwear, runningwear, skiwear, swimwear, tenniswear, and so forth. According to an advertizement, Albert's Dancewear (a Manhattan shop) sells bodywear (body here means 'torso'), footwear, and legwear. All swimwear is beachwear or poolwear, but not all beachwear or poolwear is swimwear: a jacket matching one's bikini is beachwear or poolwear but not swimwear (so far as I can tell, beachwear and poolwear are synonyms). Dog rainwear is a kind of dogwear and a kind of rainwear.

4. Various other relationships. The same article of clothing may, for instance, be both babywear and underwear, babywear and knitwear, homewear and partywear, knitwear and outerwear, rainwear and travelwear. Some items, however, do not overlap at all: for example, footwear and neckwear, knitwear and leatherwear (unless the garment contains parts that are knitted and parts made of leather), rainwear and sleepwear.

With respect to semantic categories, the words refer at least to:

1. the part of the body on which the item is worn (like eyewear).

2. the wearer (mostly human, sometimes animal) or the person who would or might be most likely to wear the clothing (like babywear, chimpwear, dogwear, and gaywear). At least two of the words falling into this category are contemptuous of the wearer (tartwear and thugwear).

3. the relationship of the clothing to other clothing (like underwear).

4. the venue where the clothing is usually worn or might be worn (like beachwear).

5. the circumstances in which the clothing is worn (like actionwear and golfwear; likewise, words like bicyclewear and scooterwear, which designate clothing for people riding bicycles and scooters).

6. the appropriate time for wearing the clothing (between-seasons wear, fallwear, fall weekend wear, Octoberwear, summerwear, spring wear, winterwear; so far as I can tell, *autumnwear does not occur).

7. how the clothing is made (knitwear).

8. what the clothing is made or consists of (like chainwear).

9. the purpose of the clothing (like artwear).

10. the color of the clothing (whitewear).

11. some other feature of the clothing (like mouseketeer wear).

12. the designer of the clothing or a person whose recognition value will help to sell it (like Angel Body Wear, Dollywear, "Evita"-wear, FergieWear, Franwear, Heidiwear, *?Jiggiewear or *?Tiggiewear, Lizwear, Lopezwear, Madonna-wear, Matwear, Munsingwear [the oldest member of this category?], Rocawear, Ruffinwear, and Williwear, collectively known earlier as designer-name ware and now as designer wear). This device was probably inspired by English brand names ending in the homophonous -ware like 
Cecilware, Corning ware, Farberware, Fiesta ware, Livingware, Nordic ware, Revereware, Tupperware, and Zephyr ware (see also the pun mentioned at Fiesta Wear below).

13. someone else for whom the clothing is named (Acid wear).

14. where the clothing was obtained (Dumpster-wear).

With regard to spelling, the tendency is toward solid spelling, which usually begins as an attention-getter in advertizing (like menswear instead of men's wear) and may later become established. ${ }^{4}$ To get even more attention, one or more internal capitals may be used: BeepwearPRO, CareWear, FergieWear, and StreetWear. ${ }^{5}$

At least two of the words have more than one meaning: outerwear means 'clothing designed for outdoor wear' (as such, it is the antonym of at-home wear, homewear, housewear, and indoorwear) and 'clothing worn over other clothing' (as such, it is the antonym of underwear); sportswear means 'sports clothes' (its usual meaning) and 'activewear'.

At least two of the words listed below have entered Japanese: menzu uea 'men's wear' and uimenzu uea 'women's wear' (Yutaka Matsuda, "Cross-Over Languages: Japanese and English [II]," Kwansei Gakuin University Annual Studies XXXV, 1986, pp. 47-80; see page 51).

The four words followed by the letters $A S$ in the list below are treated in American Speech: A Quarterly of Linguistic Usage, vol. 52, 1977, p. 33. Those given in large dictionaries or which are easily understood are not defined in the list. This collection was begun in 1979; no attempt has been made to determine whether all the businesses mentioned still exist.

Acid wear is the name of "a line of clothing for motorcyclists -- and for those who want to look like them" -- designed by Scott Chester (Anna Bahney, "Couture Motorcycles," The New York Times, 5 December 2003, pp. F1 and F8; the quotation is from page F8 of). Chester said that Acid is an acronym of Ariella Chester Industrial Design and that Ariella Chester is his daughter, but one cannot help wondering whether, when picking the name Acid wear, he did not also have in mind, chiefly in fact, the American English slangism acid 'lysergic acid diethylamide' (known informally as LSD). Acid is also the name of his company and one entertains the same thought about it too.

actionwear

active sportswear

activewear designates elastic-waist shorts, jogging suits, leotards, spandex outfits, sweatpants, sweatshirts, T-shirts, warm-up jackets, and so forth. Such clothing was once considered acceptable only when people were playing sports, but in recent years more and more have been wearing it in other circumstances too. Levi's Activewear is the brand name of a certain kind of underwear for athletes.

aerobicwear

Afri Wear is the name of an American company that makes clothing appealing to American Blacks. 
Angel Body Wear. "Mr. Corella's loving family includes his father, who has switched from selling beer to Angel Body Wear, dance wear named after his son" (Anna Kisselgoff, "Television Review: Four Regular Guys Who Work in Tights" [ = review of "Great Performances: Born to Be Wild: The Leading Men of American Ballet Theater," a documentary film made for television], The New York Times, 3 February 2003, p. E6). Reference is to Ángel Corella, a ballet dancer.

around the clubhouse wear. See breakfast wear and clubwear.

Artfulwears.com is the Internet address of an American company selling at least bags and purses (floruit 2006-2007).

artwear 'works of art that can be worn as clothing or accessories'. A synonym is wearable art.

athletic footwear

athletic wear athleticwear

at-home wear

babywear

basketwear, as in "a nylon basketwear doubleknit boxy jacket".

bathing wear. "We wear our turn-of-the-century bathing wear" (Alice Fredericks, of Ottawa, Illinois, born around 1914, quoted in The New York Times, 22 August 1994, p. A8).

\section{beachwear}

beepwear. "Time for a change: Timex and Motorola show off their Beepwear pager at CES" (the caption of a photograph, Newsweek, 19 January 1998, p. 8). Timex/Motorola Beepwear, a beeper worn on the wrist, was introduced in 1997. New York of 21 September 1998 mentions BeepwearPRO (p. 48). See wristwear.

\section{bedwear}

beltwear 'gadgets that can be worn on a belt'. The word appears in the caption of a photograph accompanying Kim Clark's "Hey, buddy, is that a Palm Pilot under your armpit, or are you just lumpy?” (U.S. News \& World Report, 26 June 2000, pp. 70-71), which deals with the problem that certain people have of where to put all the electronic gadgetry they carry around with them (p. 70). A section of the article is headed Body wear and begins "Let's face it. There are only a limited number of places on the body that people can comfortably carry gear. One of these is the torso". Another section is headed Wrist wear and deals with gadgets that can be worn on the wrist (see wristwear).

between-seasons wear. This term seems to be British only.

\section{bicyclewear}

bikewear

billboard underwear (quotation mislaid)

bodywear body-wear was originally a manufacturers' euphemism meaning 'brassieres and girdles' and currently means 'clothing which accentuates a person's figure'. The older sense of the word is now carried partly by the euphemisms intimatewear and, partly, by slimwear. See beltwear.

bondagewear 'clothing worn by people engaging in sadistic or masochistic sex; clothing 
modeled on clothing worn by people having sadistic or masochistic sex'. Both kinds of clothing feature leather and chains. See chainwear, fetishwear, leatherwear, and rubberwear.

boudoir-wear. "She fetishized the accouterments of her sexual obsession -- dedicating herself to finding the best and most economical lubricants, the most sex-friendly boudoirwear" (Zoe Heller, "The Beauty of Submission: Toni Bentley rhapsodizes about a spiritual awakening and anal sex.," The New York Times Book Review, 3 October 2004, pp. 36-37; the quotation is from page 37).

\section{boys' rough-and-tumble wear}

\section{boys' wear boys wear boyswear}

breakfast wear. An advertizement for Bermuda in The New York Times of 21 January 1999 shows the many purposes which Bermuda shorts could serve: "breakfast wear, morning stroll wear, mid morning coffee wear, shopping wear, lunch wear, walk on the beach wear, golf wear, around the clubhouse wear, pre-cocktails wear, cocktails wear, horse and buggy wear, nightcap wear" (Travel Section, p. 37). It was repeated on 24 January 1999 (Travel Section, p. 15). A shorter version appeared on 23 February 2000 (p. A6) and 1 March 2000 (p. A6) and in The New York Times Magazine of 27 February 2000 (part 2, p. 45).

\section{bridalwear}

brunchingwear. $A S$.

businesswear 'office wear'. See office wear officewear.

Cameo Water Wear is the name of a shop in Manhattan, New York, selling swimwear. careerwear 'office wear'. See office wear officewear.

CareWear 'a brand of clothing for people who care about HIV-positive people'. The clothing has various slogans on it. See sloganwear.

Caribbean wear. The phrase "Caribbean Wear for Children, Women and Men" appears in an advertizement for Tinkerbell, a shop, on page 9 of Discover St. Vincent \& The Grenadines: 1998/9.

casual wear $\sim$ casualwear 'clothing suitable for use except on semiformal and formal occasions'. This is largely a designers' and advertizers' word. Occasionally it is found in the general press, as here: "Blindingly attired in bright clashing casual wear, Mr. Bartlett exercises a timing and inflection as precisely wrought, in its way, as the Wedgwood china his character cherishes" (Ben Brantley, "Theater Review: Politically Incorrect And Proud to Show It," The New York Times, 4 October 2001, p. E5).

chainwear 'bondagewear emphasizing chains'. See bondagewear and fetishwear.

children's wear $\sim$ childrenswear

chicwear 'chic clothing'. The word appeared on the outdoor sign of Sara Boutique, a women's clothing shop at 254-10 Northern Boulevard, Douglaston, New York, at least in August 2000.

chimpwear 'clothing made for a chimpanzee' (Daily News, New York, 23 August 1987, p. 20). Probably a nonce word.

chocolatewear. "Chocolatewear" is the title of Florence Fabricant's note about "a 
presentation [in New York City] of chocolate fashions to benefit Fight AIDS" in The New York Times of 27 October 2004 (p. F10), this presentation being part of the Seventh Annual Chocolate Show, the goal of which is to make people aware of foods made with chocolate (see www.chocolateshow.com and the advertizement in The New York Times, 3 November 2004, p. F14). "Chocolatewear" is probably either Fabricant's or a newspaper staffer's nonce word. The phrase "chocolate fashions" appears in the advertizement. Although the advertizement was published after the note, the drafter of the former probably did not take it from the author of the latter. Rather, Fabricant probably took it from publicity material distributed by the organizers of the show.

cicadawear 'clothing with wording referring to cicadas' (James Godman, "Welcome to Cicadaville (Enter at Your Own Risk)," The New York Times, 25 May 2004, p. F3). Coined by Godman, this jocular nonce word is used once in his article. Examples of cicadawear are a shirt inscribed "Cicada Go Crunch" and one inscribed "Resistance Is Futile. Join Brood X".

clubwear 1. 'clothing suitable for wearing in nightclubs' (probably a synonym of latenight wear). 2. 'clothing suitable for wearing in health clubs' (at least in 2004, part of a sign outside a clothing store on Horace Harding Expressway around 252 Street, in Queens, New York, read "GYM AND CLUB WEAR"). The word is not a synonym of around the clubhouse wear, which is a nonce word meaning 'clothing suitable for wearing at country clubs, golf clubs, and the like'.

cocktailwear 'clothing for cocktail parties' (Manhattan Yellow Pages, 1996-1997, p. 197) cocktails wear (see breakfast wear).

coolfootwear (lower-cased) is the jocular name of one of nineteen kinds of imaginary e-mail listed in M.K. Mabry and J. Sweetwater's "E-Mail You Should Be Leery Of” (The New York Times, 9 May 2000, p. A25).

comfort wear, a euphemistic synonym of incontinence wear (q.v.), is used by at least one American manufacturer to describe its underpants for incontinent people (details mislaid).

costume wear 'clothing for a costume ball'. "Festive costume wear" was used in the English translation that appeared at the bottom of the screen during the broadcast of "Le Journal" (a news program in French prepared at Télé 5 in Paris, France) on WNYE-TV (Channel 25) in New York City on 29 December 2003.

cowboywear. This synonym of westernwear $\sim$ western wear $\sim$ Western wear is now the frequent if not universal name for westernwear in Santa Fe, New Mexico.

crocus wear. "On the Street: Crocus Wear" is the title of Bill Cunningham's note in The New York Times of 17 April 2005 (Styles Section, p. 4) that begins "Colorful spring coats have invaded the territory of the classic trench. The takeover attempt started last year with the popular short pink coat. This year's pink is deeper or ombré. Inroads are also being made by spring green, forsythia yellow and turquoise [...]". Thus, the brightly colored coats are likened to crocus in two ways: they exist in several bright colors and they are harbingers of warm weather (in New York City, crocuses are the first flowers to bloom).

Crown Wear was a brand of clothing at least in 1972 and thereabouts. 
cruisewear 'clothing suitable for passengers on cruiseships'

cyclewear 'clothing suitable for cyclists'

dancewear. By 2004 the word had become widespread in professional dancing circles, as we see, for example, from its appearance seven times in the Queens, New York, Yellow Pages of that year (under "Dancing Supplies," p. 229).

\section{daywear}

designer-name wear $\sim$ designer wear 'clothing that has a label showing the designer's name'. "I am writing as a disheartened consumer to express my distress over the recent influx of designer-name wear into local retail children's stores" (Jean Richardson, of Arverne, Queens, New York, letter to the editor, Queens Chronicle, 28 March 2002, pp. 8-9). "Designer Wear for the Sweat Circuit" is the title of a section of Ruth LaFerla's "Front Row" in The New York Times of 18 July 2003 (p. B8).

Designer welfare-wear is the heading given by the newspaper's staff to a letter to the editor of Daily News (New York) of 3 January 1996 (p. 30). The writer, Robert S. Cullen, protested that a certain person on welfare could afford a designer sweatshirt.

diningwear. $A S$.

doggie-wear 'dogwear', possibly a nonce word, is used in New York Post of 3 April 1993 (p. 4). See dogwear and Woof Wear.

dogwear 'clothing for dogs' is used in The New York Times of 1 April 1987 (p. B1). Dogwear is the name of a store in Manhattan, New York, selling such clothing. HAMPTON DOGWEAR is a sign in a certain store in The Hamptons (see the photograph in Daily News, New York, of 3 June 2002, p. 3). Dog-wear, an adjective, is used in The New York Times of 15 October 2000: "a dog-wear company" (p. 8). See doggie-wear and Woof Wear.

Dollywear '[hypothetical] clothing with Dolly Parton's label'. This nonce word, presumably coined by Linda Stasi, appears in her column entitled "Sound Bites" (Daily News, New York, 25 October 1993, p. 17). See Franwear.

Double Wear Stay-in-Place Makeup is a brand of makeup.

dress-for-success wear. "[...] Miyake (a Japanese Chin named for a favored designer of her dress-for-success wear)" (Robin Finn, "Public Lives: The Future's Paying Off Nicely for a Trend-Spotter," The New York Times, 6 June 2001, p. B2). See the second quotation at innerwear.

dresswear. Dresswear Market is the name of a dress shop in New York City.

Dumpster-wear. "Their men--whom one hardly saw, even though they are traditionally charged with dealings with gadje--had kept their moustaches but exchanged their traditional togs for the cheap suits and Dumpster-wear of poor people the world over" (Isabel Fonseca, Bury Me Standing: The Gypsies and Their Journey, New York, Alfred A. Knopf, 1995).

earwear. Ritz Earwear Inc., in Lake Katrine, New York, makes custom jewelry for the ears.

easywear 'clothing for anything but formal occasions'. I heard this word on a television program broadcast in New York City sometime during the first two weeks of June 2004.

eveningwear

"Evita"-wear and husswear are respectively an ephemeralism and a nonce word 
appearing in "Murder accessories" (New York Post, 7 December 1996, p. 28), which deals with "femme fatale fashion". "Evita"-wear is women's clothing in the style of Evita Perón, which enjoyed a bit of popularity after the film "Evita" appeared (the double quotation marks in "Evita"-wear allude to the film), and husswear is clothing typical of hussies. A synonym of husswear is tartwear.

executive wear 'office wear'. See office wear officewear.

exercisewear 'clothing suitable for people engaging in physical exercise'. See fitnesswear.

eyewear. The word is misspelled in DABO EYE WARE, the name of a business at 41-01 Kissena Boulevard, Flushing, New York, and in Vintage Eyeware of New York, Inc., the name of a company at 41 Seventh Avenue South, New York, New York. For more misspellings, which are occasional with words ending in -ware and -wear, see fetishwear and neckwear.

fall weekend wear 'clothing suitable for wearing on weekends in the fall' is used in an advertizement in The New York Times, 22 December 1999, p. B16.

FergieWear 'clothing carrying the label of Sarah Ferguson [once the Duchess of York, she is often called Fergie informally]'. The word is used in double quotation marks in A.J. Benza and Michael Lewittes's "Hot Copy" in Daily News (New York) of 28 June 1996 (p. 28).

fetishwear 'clothing worn during fetishistic sex; clothing expressing a sexual fetish' is used in New York of 28 November 1994 (p. 44), Daily News (New York) of 30 July 1997 (p. 18), Newsday (New York) of 6 December 1998 (p. B13), and New York Post of 16 August 2000 (p. 26). New York of 6 November 2000 quotes a sign in which the word is misspelled: "Indeed, a tattered paper sign advertising Filter 14's Halloween party promises free admission to anyone who dresses up as a 'superhero,' 'any character from a Bill Murray film,' or--horror of horrors--in 'fetishware”" (p. 57). See bondagewear, chainwear, and leatherwear.

Fiesta Wear is the title of an article by Jane and Michael Stern in The New York Times Magazine of 8 May 1994 (pp. 56-57), which deals with shops selling partywear in Los Angeles that cater to a largely Hispanic clientele. This nonce word, which is not used in the body of the article, puns on Fiesta ware (the name of a kind of dinnerware) and alludes to the Spanish-origin English word fiesta. For more puns, see Mountain Hardwear, Share Wear, and softwear.

fitnesswear 'exercisewear'.

flapperwear 'clothing typically worn by flappers'. "NEXT TIME, CARROT STICKS A 1929 scheme to help women fit into flapperwear" is the caption of a photograph in The New York Times of 29 December 1999 (p. F6).

\section{fleecewear}

folkwear 'clothing patterned on folk costume'. "Fashion Diary: Folk Wear For the World" is the title of Guy Trebay's article in The New York Times of 1 March 2007 (pp. G1 and G5) about clothing patterned on Dutch folk costumes and tapestry (the word is not used in the body of the article). 


\section{footwear}

\section{formalwear}

Franwear '[hypothetical] clothing with Fran Lebowitz's label'. This nonce word, presumably coined by Linda Stasi, appears in her "Sound Bites" in Daily News (New York) of 25 October 1993 (p. 17). See Dollywear.

frigidwear 'clothing put in cold storage', a nonce word, is found in New York of 7 June 1993 (p. 64).

funwear 'leisurewear'. See Rocawear.

FurWear.com is the name of an online furshop (at least on 17 December 2000 and thereabouts).

Gap-wear 'clothing with the Gap label', possibly a nonce word, is used in New York Newsday of 20 July 1992 (p. 11).

gardenwear

gaywear 'clothing which appeals or is presumed to appeal to gays'

gentlemen's ware. See ladies' wear ladies wear for a citation dated 1887. Gentlemen's ware is now called men's wear and menswear. However, women's wear has not displaced ladies' wear ladies wear.

gentrywear is used by Edwin G. Burrows and Mike Wallace in their book Gotham: A History of New York City to 1898 (New York and Oxford, Oxford University Press, 1999, p. 722).

Gigwear. "If you missed The Stones but want the tour jacket, take heart. That big space they're feverishly working on down on lower Broadway is going to be the world's largest 'gig' store, where anything rock ' $n$ ' roll will be available for the buying. And, yes, it's going to be called 'Gigwear"' (Linda Stasi with A.J. Benza and Michael Lewittes, "Hot Copy," Daily News, New York, 30 October 1994, p. 33).

girls' wear $\sim$ girls wear $\sim$ girlswear

glove wear $\sim$ glovewear. The first variant is listed in Webster's Third New International Dictionary of the English Language: Unabridged (s.v. wear).

golfwear 'clothing suitable for golfplayers'. "Urban Golfwear Faces a Tough Course: Clothing Maker Has Everything but a Traditional Sales Outlet" is the title of an article by Sherri Day in The New York Times of 11 March 2003 (p. C6) about "golf apparel and accessories". ${ }^{6}$ See breakfast wear and witness wear.

\section{grungewear}

gymwear $=$ working-out wear $\sim$ workout wear. See clubwear.

\section{handwear}

headwear. This word makes its appearance in dictionaries no later than Webster's New International Dictionary of the English Language: Second Edition: Unabridged (1934), where it is underdefined as 'headgear', which should be 'headgear 1a'. "Patriotic headwear: tin stovepipe hat made for the campaign" is the caption of a drawing in American Heritage: Civil War Chronicles (1993, p. 14). "So is Queen Elizabeth's reign nothing more than a 50year accessories story, the saga of a woman who rules because of some sensational headwear?" (William Norwich, "Propping Up The Monarchy: God save the accessories, 
please! It's Queen Elizabeth's Golden Jubilee," The New York Times Magazine, 19 May 2002 , pp. 55 and 62; the quotation is from page 62). "At a gathering of the Union of Islamic Organizations of France last weekend, the group's leader proposed that Muslim girls learn to use bandannas as 'discreet headwear'" (Hélène Fouquet, "France: Bandannas Not Ruled Out," The New York Times, 17 April 2004, p. A5). "[...] an exhibition of Jewish headwear at the Hebrew Home for the Aged in the Bronx [...]" (Lauren Redniss, "Op-Art," The New York Times, 22 May 2004, p. A17).

healthwear 'clothing promoting good health'. Sunglasses made by a certain American firm (details mislaid) have the trademarked words "VISUAL healthwear".

Heidiwear 'clothing carrying the label of Heidi Fleiss [a former Hollywood madam]'. Such clothing was sold at least around September 2000.

hipwear "Rapwear. Soulwear. Hipwear" is the title of an article by Diane Cardwell in The New York Times of 14 February 1993 (sec. 9, p. 5), which deals with clothing worn by the hip, by those who want to be hip, by those who have "soul," and by rappers. All three words may be nonce words. The spelling hip wear could be seen on the 10-PM News, WNYW-TV (New York City), on 9 December 1998.

hip-hop-wear is defined as being (at least) "Mecca hats, Avirex jackets, [and] FUBU jeans” in Ethan Brown's article “Tunnel Vision” (New York, 26 April 1999, p. 15).

\section{holidaywear holiday wear \\ homewear \\ horse and buggy wear. See breakfast wear. \\ hot-weather wear \\ housewear}

humanwear. This is a nonce word occurring in Blue of August-September 2000 (vol. 3, no. 4), where Amy Schrier, founder of the magazine, defines the word as 'apparel that facilitates movement, action and freedom, which naturally adapts to the physical needs of the human body. Performance + style. For active men + women who want to wear clothes and feel free' (p. 52).

husswear. See “Evita”-wear.

Imperial Wear is the name of a men's clothing store with branches in Manhattan and Manhasset (both in New York State).

Inaugu-Wear 'clothing with an imprint referring to an inauguration'. "Inaugu-Wear for Sale: Put the President-elect on your chest, and help pay for his swearing-in" is the title of an article by Marian Burros in The New York Times of 27 December 1992 (sec. 9, p. 8). This is either a nonce word or an ephemeralism.

incontinence wear 'clothing, usually underclothes, designed for incontinent people'. "Professionals disagree over the use of incontinence wear" (Nancy L. Mace and Peter V. Rabins, The 36-Hour Day: A Family Guide to Caring for Persons with Alzheimer's Disease, Related Dementing Illness and Memory Loss in Later Life, rev. ed., New York, Warner Books, 1992, p. 112). See comfort wear.

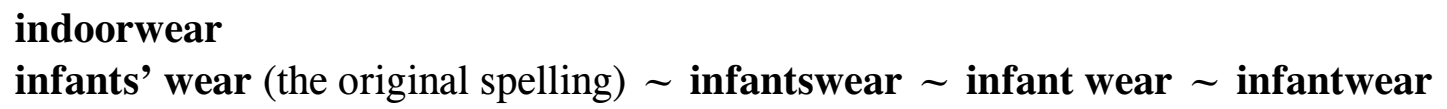


innerwear. "Innerwear as Outerwear" is the title of an article by Bernadine Morris in The New York Times of 28 March 1993 (sec. 9, p. 8), which notes that certain garments once considered underwear may now be worn as outerwear (see too the quotation at sleepwear). Although underwear could have been used here, innerwear was coined in its stead to make the contrast between inner and outer garments clear. "Inner Wear" is the title of an appeal to subscribe to The New York Times in the issue of 8 August 1994 (p. B8): "You're not dressed for success till you've absorbed as much of the news of the day as time allows. New of fashion, the world, the arts, the rest -- in the pages of The New York Times". The appeal shows a mannequin covered only with newsprint. At least in its second application, this is a nonce word. See dress-for-success wear.

intimate wear is characterized as a euphemism in Stuart Robertson's The Development of Modern English (second edition, revised by Frederic G. Cassidy, Englewood Cliffs, Prentice-Hall, Inc., 1954, p. 249). See bodywear and slimwear.

in-wear "clothing for those who want to be "in",

Iron-Wear is the brand name of a certain kind of athletic underwear.

jeanswear. It is hard to see the purpose of this word. Is not jeans enough?

*? Jiggiewear or *?Tiggiewear. In January 2002 I saw a garment bearing one of those brand names but did not get close enough to make out the first letter with certainty.

jockwear 'athleticwear' is a slangism appearing in the caption of a photograph in The New York Times Magazine of 24 January 1999 (p. 64): "Mick in jockwear (football pants and jersey".

\section{joggingwear}

Juicy Wear is the name of a brand of lipstick sold by Lancôme. An advertizement in The New York Times of 18 July 2004 reads in part "JUICY WEAR DUO / EXTREME WEAR COLOUR, SEALED IN JUICY SHINE. I AM TEMPTED. ULTRA-LASTING FULL COLOUR AND SHINE LIP DUO / > LIPS ARE KISSABLE IN SMUDGEPROOF COLOUR / > PATENTED JUICY SEAL ${ }^{\text {TM }}$ TECHNOLOGY FOR EXTREME WEAR AND SWEET SHINE / > 8-HOUR WEAR, 15 JUICY SHADES" (Styles Section, p. 7). When spellings like colour and theatre are found in American English after color and theater became established there, as in the quotation, they are snobbish imitations of British usage. See lipwear.

\section{juvenile wear \\ kid's wear kids' wear kidswear \\ knitwear}

ladies' wear ladies wear. The earliest use I can find of the first variant is from 1887: "There is now a market for hardware of all kinds; agricultural implements, axes, wagons, carriages, harnesses, pianos and organs; also for prints, fine cottons, mill and mining tools and machinery, hosiery, flannels, woolens for ladies' and gentlemen's wear; glassware, lamps and gas fixtures, furniture, leather, hats, trunks and valises, firearms, scientific and surgical instruments, etc". (Fanny Chambers Gooch, Face to Face with the Mexicans, edited, with an introduction, by C. Harvey Gardiner, Carbondale and Edwardsville, Southern Illinois University Press, London and Amsterdam, Feffer and Simons, Inc., 1966 
[= an abridged and edited version of Face to Face with the Mexicans: the Domestic Life, Educational, Social, and Business Ways, Statesmanship and Literature, Legendary and General History of the Mexican People, as seen and studied by an American woman during seven years of intercourse with them, New York, Fords, Howard, \& Hulbert, 1887]; the quotation is from page 225; the author lived in Mexico from 1880 to 1887 and the precise date of publication was 24 December 1887). See gentlemen's wear and women's wear.

lapel wear 'security pins given to people approved to meet Senator-elect Hillary Rodham Clinton' is a nonce word in James Baron with Linda Lee, "A Chance for Tea And a Signing," The New York Times, 20 December 2000, p. B2.

late-night wear is probably a synonym of clubwear. "11:30 P.M. The latest in latenight wear: Rosana Casagrande gets ready for a fashion show. Page 2" (the caption of a photograph, The New York Times, 16 September 2001, sec. 14, p. 1). The article on page 2 ("Style Wars: Getting Past the Velvet Rope") supports my supposition.

leatherwear. Certain pieces of leatherwear are bondagewear and fetishwear.

legalwear 'clothing worn by members of the legal profession as symbols of their status'. "Michael Morling, store manager of Thresher \& Glenny, purveyor of wigs and legal wear on Chancery Lane since 1755, said that he thought the chancellor was tipping the scales but that he was not worried about the outcome" (Warren Hoge, "London Journal: Mothball the Fusty Legal Regalia? Britons to Judge,” The New York Times, 16 May 2003, p. A4). The term is also used in the caption of one of the photographs accompanying the article: "Thresher \& Glenny on Chancery Lane in London has been a purveyor of wigs and legal wear since 1755, and Michael Morling, the shop manager, is confident it will not go out of business soon". Since legal wear includes wigs, the caption is not perfectly worded (either delete "wigs and" or insert "other" between "and" and "legal").

legwear. Activa Compression Legwear is a brand of compression stockings.

leisurewear

lipwear refers to lip balm in "ChapStick / Holiday Lipwear that's Giftable / Great Stocking Stuffer" (sign in various pharmacies in New York City in December 2006). See Juicy Wear.

Lizwear is the brand name of a certain kind of women's clothing.

logo wear 'clothing on which the designer's logo is visible' (Daily News, New York, 31 August 1995, p. 67).

Lopezwear. "Lopezwear Is Born" is the title of a note by Ginia Bellafante in The New York Times of 1 May 2001 announcing that Jennifer Lopez, "a celebrity with the power to eclipse," will "further capitalize on her fame in a new role as a designer of jeans and Tshirts" (p. B9). Whether the clothing will indeed be marketed under that name is not clear.

loungewear. The first morpheme of this word is the verb lounge, not the noun lounge. The word is misused in "LEATHER LOUNGEWEAR," the title of a Bloomingdale's advertizement for leather sofas in The New York Times of 27 October 2002 (sec. 1, p. 39). *LEATHER LOUNGEWARE would have been better, but even that form is not good. See lounging wear.

lounging wear has for at least several years been obsolete, its replacement being 
loungewear. On the dropping of -ing, see David L. Gold, "Frypan versus frying pan: A Trend in English Compounds?," American Speech: A Quarterly of Linguistic Usage, vol. 44, 1969, pp. 199-302. For another instance of such dropping, see working-out wear. The awning of a clothing store in Harlem, a New York City neighborhood, still had the older form in August 1996 (The New York Times, 20 August 1996, p. A15).

lunchwear lunchingwear. AS. See breakfast wear.

Madonna-wear. "Madonna has whipped aerobics queen Gilda Marx into a sweat. Marx's husband, Bob, was quoted in the Los Angeles Times as saying that the couple's exercise-clothing company had been approached to design and market a line of Madonnawear" (New York, 18 January 1993, p. 10). This is either a nonce word or an ephemeralism.

Masterwear Corporation is the name of a business. I have been unable to determine what it does.

matching spousewear. "Matching spousewear" was used on the 10-PM News of WPIX-TV (New York City) on 15 February 1998 in a report about a married couple in Fitchburg, Massachusetts, who for many years have worn matching clothing every day. Spousewear probably occurs only in the collocation matching spousewear.

maternity wear 'clothing for pregnant women'. "Maternity wear rarely looks good belted at the waist after the bump has disappeared" (The Guardian, 1987). Since Lena Bryant (also known as Lane Bryant) "designed what is considered the first maternity wear" in the United States (Ellen Williams and Steve Radlauer, The Historic Shops \& Restaurants of New York, New York, The Little Bookshop, 2002, p. 73), it would be a good idea to try to see whether she coined the term (according to Williams and Radlauer, she began making dresses in her apartment on the Lower East Side of Manhattan in 1900). Bryant, however, was not the first to make maternity wear: "Antiques Roadshow," an American television program, once showed a maternity-mourning dress made in the late 1840s or early 1850 s (its overfullness in the abdominal area demonstrates it to be a maternity dress and its black color proves it to be a mourning garment).

Matwear was the name of a company owned and operated by Patrick Boylan that made maternity clothes (see Penelope Green, "Mirror, Mirror: Couturier to the Heavens and Above," The New York Times, 9 December 2001, Styles Section, p. 8).

medical wear 'uniforms for medical personnel'. Image First Medical Wear Incorporated is the name of a corporation located at 43-12 54 Road, Maspeth, New York.

medieval wear 'Halloween clothing resembling clothing worn in medieval Europe' is used in Pamela LiCalzi O'Connell's “Online Diary: Haunted, Schmaunted” (The New York Times, 24 October 2002, p. G3). ${ }^{7}$

men's wear menswear. See gentlemen's wear.

mid morning coffee wear. See breakfast wear.

mini-eyewear 'sunglasses for babies', possibly a nonce word, is used in The New York Times of 29 May 1994 (sec. 9, p. 3).

misses' wear (so spelled) was in 1826 advertized for sale by Samuel Lord (born in Great Britain) and George Washington Taylor (his wife's American-born cousin) at their store on Catherine Street in New York City. 
morning stroll wear. See breakfast wear.

Mineral Wear is the name of an American brand of cosmetics (they contain minerals). This is the only use of wear that I have found which does not designate clothing in the conventional sense.

Mountain Hardwear is the name of an American company that manufactures camping equipment, including clothing. Hardwear is a pun on the computer term hardware. For more puns, see Fiesta Wear, Share Wear, and softwear.

mouseketeer wear 'clothing with an imprint of Mickey Mouse and his friends' is used in Newsweek of 22 July 1985 (p. 65).

multiculturally aware wear (quotation mislaid).

Murf Wear is the name of a company in Tustin, California, that designs surfwear.

Munsingwear. $A S$.

Musketwear

muslinwear

neckwear is misspelled in "Come meet the Chairman of Stonehenge Ltd. and creator of the Cocktail Colors Collection neckware program supporting Mothers Against Drunk Drivers" (Macy's advertizement, The New York Times, 25 November 2001, p. A15). The word is used humorously, to mean 'feathers around the neck [of a bird]', in the caption of a photograph in The New York Times of 2 December 2003: "Drawn to a male with a colorful style are the female bluethroats, which choose their sexual partners based upon the brilliance of their neckwear" (p. F4).

Net Wear is the caption of a notice about a tenniswear sale in New York of 21 August 1995 (p. 50).

nightcap wear. See breakfast wear.

nightwear

nuclearwear 'outerwear with lettering calling attention to a certain town on the West Coast of the United States whose residents had been exposed to dangerous amounts of radiation', possibly a nonce word, was used in a New York City television news program early in May 1994. I did not catch the name of the town, which was mentioned.

nurses wear. Nurses wear, physicians wear, and telemetry staff wear are used on page 124 of John Seabrook's “Annals of Style: The White Dress: What Should Nurses Wear?" (The New Yorker, 18 March 2002, pp. 122-127).

Oberwear 'clothing typically worn by waiters in cafes in German-speaking countries', a nonce word, is found in Brenda Fowler, "Vienna's Quirky Coffeehouses," The New York Times, 27 December 1992, Travel Section, pp. 8-9. The stem of this word is informal German Ober 'headwaiter' (shortened from German Oberkellner 'idem'). Fowler does not limit the word to the clothing of head waiters. See waitresswear.

Octoberwear 'fallwear'. A nonce word. "Octoberwear" is the title of Ellen Tien's note in The New York Times of 10 October 2004 (Styles Section, p. 3), about clothing to "bridge the transition from crisp weather to cold".

office wear officewear 'clothing appropriate for the office and business in general'. Synonyms of this word, which is applied mostly to women's clothing, are businesswear, 
careerwear, and executive wear. The four terms seem to be used only by manufacturers, mostly in advertizing.

OneDerWear Disposable Cotton Panties “It's gross to 'haul' dirty panties home from a trip, and inconvenient to wash them in a hotel bathroom. Now you don't have to, thanks to these 'ultralightweight' cotton panties that you can either 'toss or wash'" (the panties are so described in This Week of 25 June 2004 [p. 34], which gives the manufacturer's address as Onederwear.com). The name puns on one and wonder.

outerwear

overwear 'outerwear'

papal wear 'ecclesiastical clothing worn by the pope'. "As luck would have it, the new papacy has produced an equally colorful chronicler of papal wear, Rocco Palmo [...]" (Ian Fisher, "From the House of Benedict, Tradition as Chic," The New York Times, 19 February 2006, sec. 4, p. 14). See Roman Catholic Church wear.

\section{partywear}

peasantwear. "[...] patched jeans and embroidered shirts of the international peasantwear economy" (Jon Pareles, "Woodstock: Old-Time New-Age Karma," The New York Times, 25 October 1996, pp. C1 and C29; the quotation is from page C1]). On 29 February 1999, "Chinese peasantwear" was mentioned on the 10-PM News of WNYW-TV (New York City).

physicians wear. See nurses wear.

playwear 'clothing, especially children's clothing, suitable for wearing during play'

poolwear

posewear 'garments worn by bodybuilders while posing; scanty

clothing worn by people appearing in soft sexography' ${ }^{8}$

pre-cocktails wear. See breakfast wear.

prisonwear. "Prisonwear takes a retro turn: eye-catching stripes right out of a Cagney movie" (a blurb accompanying Thomas Vinceguerra, "The Clothes That Make The Inmate," The New York Times, 1 October 2000, sec. 4, p. 2; the word does not appear in the article itself).

Pub Wear, a facetious nonce word, occurs on page 29 of Nancy Freiberg's "Tales of Healy" (Georgetown Magazine, Washington, DC, vol. 38, no. 2, spring/summer 2006, pp. 18-29), where she mentions the Georgetown Pub and Center Café, which from its founding in 1973 until some years later was located in the basement of the Healy Building (on the campus of Georgetown University, Washington, DC), and quotes this sentence from an essay by Jonathan Bacal in Joseph Durkin, ed., Swift Potomac's Lovely Daughter (a book about Georgetown University published in 1990): "No Hoya's wardrobe was complete without a special pair of shoes which are worn only in the Pub" (Hoya is the informalism used at the school to mean 'student at Georgetown University'). Thus, Pub Wear means 'special shoes worn by patrons at the Georgetown Pub and Center Café'.

Queenswear is the name of a women's clothing shop that has been in business in Manhattan, New York, at least since around 1994, its current address being 392 Broadway. racewear 'special clothing worn by racers'. "There was the story of the Southern auto 
racer, trying to buy clothing in California, who couldn't make the vendor understand that 'rice wire' translated to 'race wear"" ("Instructor helping students modify the y'all drawl," The Monitor, McAllen, Texas, 30 August 1992).

\section{rainwear}

ranchwear 'clothing suitable for ranchworkers'. In the western United States, the term has been prevalent at least since the early 1990s, whereas westernwear $\sim$ western wear Western wear (q.v.) is used elsewhere in the country. Corral West Ranchwear is the name of a store in Cheyenne, Wyoming.

rapwear. See hipwear.

ready-to-work wear. See workwear.

repairwear. "CLINIQUE / repairwear / intensive night cream" is so advertized in The New York Times Magazine of 17 October 2005 (p. 7). "CLINIQUE / repairwear / intensive night cream / very dry skin formula / crème nuit réparation intense / spéciale peaux très sèche" is advertized in The New York Times of 28 November 2004 (sec. 1, p. 15). "C / Clinique / repairwear / anti-aging makeup / SPF 15" is advertized in The New York Times of 12 September 2005 (p. A7).

resort wear resortwear 'clothing suitable for wearing in resorts'. See vacation wear. retrowear 'clothing of yesteryear worn now by people who want to make a statement' 42).

riding wear. "English riding wear" is mentioned in New York of 27 September 1999 (p.

Rocawear is the name of a brand of clothing (at least T-shirts and jeans) sold at least since 1999. "Jay-Z says he's over the whole 'ghetto fabulous' diamonds-and-furs look, and the flashy lifestyle that goes with it. To see his new Rocawear women's line, you'd believe him. The collection [...] features low-waisted velour track suits, satin bomber jackets, dropped tops and drawstring short shorts. It's young and sporty -- but not ripping with logos. 'It's funwear, not thugwear, ' explained Damon Dash, CEO of Rocawear, who is also working on ladies. 'It's a reflection of us. Not too dressy, not too couture-ish" (Alev Aktar and Holly Russel, "Rocawear for Ladies," Daily News, New York, 13 December 2001, p. 73). Were the spellings Rock-A-Wear and Rockawear, once used and possibly now obsolete, ever official?

Roman Catholic Church wear "ecclesiastical clothing worn by clergy of the Roman Catholic Church' (Jason Horowitz, "Style Secrets Of the Pope's Tailor," (The New York Times, 14 April 2005, p. G10). See papal wear.

royalwear was used once by each of two newscasters on the 5-PM news of WABC-TV (New York City) on 25 June 1997 to designate the gowns auctioned by Diana the Princess of Wales.

rubberwear 'clothing made of rubber'. "In April 1974 the store became 'SEX' and was filled with sadomasochistic and pornographic references as well as clothes made of leather and rubber, including 'rubber-wear for the office"" (Alan Riding, "A Fashion Idol's Odyssey From Punk to Prosperity: Museum Celebrates a Designer Who Shocked Britons," The New York Times, 21 April 2004, pp. E1 and E7; the quotation is from page E7). Rubberwear is likely to be fetishwear and is often bondagewear. 
Ruffinwear is a brand name of women's clothing designed by Clovis Ruffin.

ruggedwear

runningwear

samplewear (quotation mislaid). The meaning is presumably *'sample garments which are eventually put on sale, usually at reduced prices'.

scantwear 'scanty clothing meant to be erotically stimulating'. "CHAUVINIST -MACHO: for unisex scantwear for modern, liberated people. Write for brochure to [...]" (classified advertizement, Sunday Times, Cape Town, South Africa, 13 July 1983, p. 24).

scooterwear. "Scooter-Wear" is the title of an editorial in Newsday (New York) of 1 April 2001 (p. A18), which deals with legislation requiring children riding scooters to wear helmets.

servants' wear is called "perpetually out of date" by T.H. Pear in his English Social Differences (London, George Allen \& Unwin Ltd, 1955, p. 174).

shapewear 'brassieres and girdles; tight clothing which accents the wearer's figure'. Smoothie Shapewear is the name of a clothing store in New York City.

Share Wear is the name of the rabbit-mask-making workshop for children held by the Staten Island Children's Museum (New York City) during Easter 1992. The word puns on the computer term shareware. For more puns, see Fiesta Wear, Mountain Hardwear, and softwear.

shopwear shopping wear. See breakfast wear.

skatewear 'clothing appropriate for skating'. The word is found in an advertizement for Stagedoor Dancewear (104-03 101 Avenue, Ozone Park, New York) in The Queens Chronicle of 7 December 2000 (p. 26). Rebecca Mead describes Silas \& Maria as 'a British skatewear brand" on page 106 of her "Letter from Tokyo: Shopping Rebellion: What the kids want" (The New Yorker, 18 March 2002, pp. 104-111).

skiwear

slimwear 'girdles'. This is a manufacturers' and sellers' euphemism. See bodywear and intimatewear.

sleepwear. "FLORIDA: SLEEPWEAR IS NEWEST SCHOOL FASHION Students in Broward County are strolling into class in pajamas and fuzzy slippers, to the consternation of school administrators. Although bedroom clothes are not expressly prohibited by the district's dress code, some schools are sending pajama wearers home. Students say sleepwear is no worse than a lot of clothing already allowed, including sweat pants and warm-up suits" (Associated Press dispatch, The New York Times, 18 March 2003, p. A26). See too Bernadine Morris's article mentioned at innerwear.

sloganwear 'clothing with slogans'. "Consumed: Go Team, Go Figure: A high-school team's nerdish name scores on the slogan-wear circuit" (the title of an article by Rob Walker, The New York Times Magazine, 18 April 2004, p. 24; the article has the spelling slogan-wear). Sloganwear seems to have originated in the United States in the 1960s. See CareWear.

slumberwear 'sleepwear'. A manufacturers' word.

Smilewear. "Then, of course, they started manufacturing my Smilewear ${ }^{\mathrm{TM}}$ briefs, and 
I never saw a penny from it" (Steve Martin, "Shouts \& Murmurs: Elián at Twenty," The New Yorker, 22 May 2000, p. 46). A fictitious brand name.

softwear. The phrase "Softwear for People" appears in an advertizement for which I have mislaid the bibliographical details. "Italian Softwear \$250" is found in an advertizement for cotton suits in The New York Times of 3 June 1999 (p. A23). Atlantic Softwear is the name of the clothing and souvenir shop at 37 Shore Road in Ogunquit, Maine. Softwear is a pun on the computer term software. For more puns, see Fiesta Wear, Mountain Hardwear, and Share Wear.

soulwear. See hipwear.

spacewear 'clothing for people traveling to and in outer space'. "It has been little noted that the advent of tourist travel in space, not to mention the prospect of stays on the International Space Station, and eventually on the Moon (or so NASA promises), presents severe fashion challenges. Zero gravity can really mess up your look. Blood rushes to the head and puffs up the face. Hair floats like seaweed in a current. Luckily for those of us with normal bodies, Star Trek tights never did take off as spacewear" (Dennis Overbye, "Findings: On The Runway: Spacewear Meant to Dazzle, Even in Zero Gravity" (The New York Times, 16 May 2006, p. F1). The word is probably a jocular nonce formation.

special-occasion wear. A handbill announcing a sale at the Young Israel of Jamaica Estates (Queens, New York) from 13 to 16 November 2005 mentions "special occasion wear". Since the term does not mean *'occasion wear that is special', a hyphen is needed instead of the first space.

sportswear $\sim$ sportwear. The latter spelling, it seems, is found only in advertizing and in Sportwear Tinted Day Creme, the brand name of a certain cream manufactured by Estee Lauder.

sport utility wear. "Sport Utility Wear For the Other Side of Your Life" is found in an advertizement for trousers in The New York Times Magazine of 29 November 1998 (pp. 1415). This term, which alludes to sport utility vehicle, seems to have no easily grasped meaning and to have been coined merely to create an association with a kind of vehicle that was becoming popular in the United States in 1998 and thereabouts.

spousewear. See matching spousewear.

spring wear 'clothing suitable for wearing in spring weather' is used in The New York Times of 25 February 1996 (City Section, p. B8).

streetwear 'clothing in the style of streetpeople or appealing to them'. StreetWear is the name of a clothing store in Manhattan, New York.

\section{summerwear}

sunwear 'sunglasses'. This word is used only in advertizing. A Salvatore Ferragamo advertizement in The New York Times of 1 February 1999 calls sunglasses "sunwear" (p. A9) as does a Whitestone Vision Center advertizement in an undated issue of Queens Business (Queens, New York) from the beginning of May 2002. The word is also appears in Pacific Sunwear of California, Inc. (the name of a retailer of casual clothes and accessories) and Sunwear Corporation (the name of a manufacturer of swimwear in New York City), where its function is merely to allude to sunshine and thus warm weather. 
surfwear 'clothing suitable for surfers'

swimwear

tartwear. 'garish clothing typical of tasteless women' "Scoffers derided the vivid colors and startling materials as tartwear, but they were always outnumbered by the enthusiasts" (Stephen McFarland, "Murder by Design: Calabria a genesis of genius," Daily News, New York, 17 July 1997, p. 4). A synonym of tartwear is husswear (see "Evita"-wear).

Tattoo Wear is the brand name of panty hose with a nonbleaching tattoo image printed on the underside of the sheer nylon; when these stockings are worn, they give the impression that the wearer has a tattoo on her skin (New York, 13 January 1986, p. 15).

\section{teenwear}

telemetry-staff wear. See nurses wear.

tenniswear

thermalwear $\sim$ thermawear 'clothing designed to retain body heat'. The English combining form is normally thermo-, so that the second variant, where the first $a$ was induced by the word thermal, is badly formed. See warmwear.

thugwear 'clothing worn by thugs'. See Rocawear.

*?Tiggiewear. See *? Jiggiewear.

townwear

travel underwear. "Women's travel underwear" (catalog issued by Magellan's, of Santa Barbara, California, and dated "early spring 2005," p. 47).

travelwear. See travel underwear.

troublewear. "Troublewear.com seeks to attract extreme-sports fans with its own brand of clothing" is the caption of a photograph accompanying Michelle Slatalla's "For the Young And the Hip, And Only On the Web" (The New York Times, 11 November 1999, p. G4), where we read that this is the name of a website which is "a high-energy world of online youth culture that celebrates surfer lingo, blaring music and the sort of jerky green graphics that remind me of Wired magazine circa 1995".

underwear. Since volume IV of A Supplement to the Oxford English Dictionary (1986) has citations dated 1872 and 1875, Webster's Ninth New College Dictionary (1990) and especially Merriam-Webster's Collegiate Dictionary: Tenth Edition (1993), which bills itself as "The Voice of Authority," are not up to date when stating that the earliest citation is from "ca. 1879".

"I recently went into Macy's at Herald Square to take advantage of a bra sale. Not seeing a directory near the entrance, I went over to the information booth and asked the woman at the counter to please tell me where I could find women's underwear. With a disdainful look, she said, 'Men wear underwear; women wear lingerie.' (Which, I now know, is on the sixth floor.)" (Ellen Heidelberger, quoted in Joe Rogers, "Metropolitan Diary," The New York Times, 24 November 2003, p. B2).

See travel underwear.

urbanwear 'clothing suitable for wearing in urban areas'

vacation wear 'clothing suitable for wearing during a vacation'. "Zoubida Mataoui, assistant director of the Moroccan National Tourist Office in New York [...], said typical 
vacation wear was generally acceptable, provided it was not too short or tight. Many Moroccans enjoy activities like swimming and so, resort wear is not necessarily unacceptable, she noted" (Ray Cormier, "Q \& A: Dressing for Morocco," The New York Times, 29 June 2003, Travel Section, p. 19). ${ }^{9}$

vintage wear "vintage clothing, that is, clothing which is out of fashion among most people and for that reason worn by others as a statement'. "Regulars here dress down in vintage wear, denim and corduroy, echoing the bohemian decor" (William Leone, "A Night Out With Michael Imperioli: The Hit Man as Host," The New York Times, 13 January 2002, Styles Section, p. 3).

Wagwear, the name of an American fashion outfitter for dogs, implies that the dogs are so happy to wear its designer clothing that they wag their tails out of sheer joy. Among its products are clothing, toys, carriers, collars, and leashes.

waistwear

waitresswear was used on "New York: Non-Stop," a program on WABC-TV (New York City) on 24 October 1998. See Oberwear.

walk on the beach wear. See breakfast wear.

warmwear 'sleepwear designed to retain body heat'

WASP-wear 'clothing typically worn by WASPs or appealing to them' (John Leland and Gregory Beals, "In Living Colors," Newsweek, 5 May 1997, pp. 58-60; see p. 59). WASP is the acronym of White Anglo-Saxon Protestant.

\section{weekendwear}

westernwear $\sim$ western wear $\sim$ Western wear "clothing inspired by the clothing of cowboys and cowgirls in the western United States'. In November and December 1994, however, American media reported that what we dudes take to be the clothing of cowboys in days of yore is actually an invention of the wardrobe designers for Hollywood westerns. See ranchwear.

where wear. "WHERE WEAR The Casio PAT2GP-1V (\$500) can tell you not only what time it is but also where you are at that time. The watch, which has a rechargeable battery, contains a miniature Global Positioning System receiver. It can download maps with premarked routes from a computer and then offer directions on its screen to guide users to their destinations" (the caption of a photograph of the watch on page G11 of The New York Times of 15 November 2001).

whitewear

Williwear Ltd. is the name of a fashion house named for its founder, Willi Smith, a designer.

windwear 'clothing designed to keep out the wind'

winterwear. See winter wonderwear.

winter wonderwear. "Winter Wonderwear" is the heading of a notice in New York Post of 11 January 1998 (p. 43) about winter clothing and "Fashion: Winter Wonder Wear" is the heading of a similar notice in New York of 24 November 2003 (p. 52). The term alludes to the phrase winter wonderland. See winterwear.

witness wear. "It's not witness wear. We're not trying to turn boys into people who are 
going to go witness and preach the gospel to their friends" (Kathy Needham, senior marketing director of Zonderkidz, the children's division of Zondervan, a Christian book publisher in Grand Rapids, Michigan, quoted in Francine Parnes, "Religion Journal: Clothes That Make a Few Statements," The New York Times, 25 January 2003, p. B6). Parnes's article deals with what she calls religion-theme apparel, that is, clothing with religious messages, like Yeshua Sportswear by God's Company (yeshua is a Hebrew male given name borne, among other people, by Jesus) and Christianitee Golfwear (a brand which includes golf shirts that say "Fairway to Heaven" and "Fore Him"). Christianitee (a manufacturer's coinage that blends Christianity and the golfing term tee) is homophonous with Christianity. Fairway to Heaven is a blend of the golfing term fairway and the phrase way to Heaven. Fore him is a blend of the golfing term fore! and the phrase for Him, which alludes to God or to Jesus.

women's wear womenswear. This word seems to have survived only in Women's Wear Daily, the name of a fashion newspaper. Otherwise, ladies' wear ladies wear is usual. See gentlemen's wear.

wonderwear. "Wonderwear" is the title of an unsigned note in Newsweek of 4 December 2000 (p. 8), which says that "next year Underoos, the children's superhero underwear from the ' 80 s, will be available for adults in Batman, Superman and probably Spider-Man versions. (And possibly Wonder Woman and Supergirl. For women.)”.

Woof Wear was the name of a business, located at 247 West 37 Street in New York City, that made clothing, jewelry, and other things for dogs (English woof is an echoic word imitating the bark of a dog). By 2 May 2003 it had either gone out of business, changed its name, or moved.

working-out wear (possibly a nonce or ephemeralism) workout wear (the usual form today) = gymwear. See lounging wear.

workwear work wear originally meant 'clothing made for workers, workclothes'; later came to mean 'clothing fashioned after workclothes'; and still later acquired the meaning 'workclothes designed by leading designers'. In the third sense, the word is synonymous with ready-to-work wear.

wrist wear wristwear 'things that may be worn on the wrist' In David Pogue's "State of the Art: Wristwear: Zap, Snap Or Zero In" (The New York Times, 24 May 2001, pp. G1 and G7), the word is applied to electronic gadgets, whereas in Eilen Tien's "Pulse: Wrist Wear" (The New York Times, 28 August 2005, Styles Section, p. 3), it is applied to bangle bracelets and roll-on beaded bracelets. See beepwear and beltwear.

yogawear 'clothing suitable for yogis'. "Bono invested in buddy Christy Turlington's yoga-wear business, ponying up \$2,000 for her Nuala togs at Bendel's..”. (George Rush and Joanna Molloy with Lauren Rubin and Kasia Anderson, "Rush \& Molloy," Daily News, New York, 27 March 2002, pp. 28-29; the quotation is from page 29). "Yoga Wear, Not Yoga, Is The Mantra" is the title of Ruth La Ferla's article in The New York Times of 15 December 2002 (Styles Section, p. 6).

youthwear. Rumble Seats Youthwear is the name of a clothing manufacturer in New York City. 


\section{Notes}

1. Collective noun is a better term than "generic".

2. In contrast, the older meaning of eyewear, 'impairment of vision due to overuse of the eyes', seems to be obsolete (but that is a different -wear).

3. See the comment at casual wear.

4. Such spellings are collectively known as advertizing spelling.

5. The internal capital letter is a vogueism, not uncommon in the world of business today, as in HarperCollins and WordPerfect.

6. Kenneth Hudson considers apparel to be diseased English, specifically, “A shopkeeper's upgrading of "clothing'". (Kenneth Hudson, The Dictionary of Diseased English, New York, Harper $\&$ Row, Publishers, 1977, p. 12). He goes on to say that "A firm can consequently be described, to someone in the trade, as 'producing curtaining, furnishing fabrics and apparel' (Daily Telegraph, London, England, 22.1.76). It is not clear why this faintly ridiculous word is found necessary. 'Apparel' is no more comprehensive than 'clothes' or 'clothing', and even the most exalted people are not ashamed to admit that they buy and wear clothes". Never having felt a need to use the word apparel in speech or in writing, I find it easy to agree with him.

7. Read Shmaunted.

8. Sexography is the value-neutral term now replacing pornography.

9. Delete the comma after so. 